\title{
The effectiveness of alcohol warning labels in the prevention of Fetal Alcohol Spectrum Disorder: A brief review
}

\author{
Gerald Thomas ${ }^{1}$, Ginny Gonneau ${ }^{2}$, Nancy Poole ${ }^{3}$, and Jocelynn Cook ${ }^{4}$ \\ ${ }^{1}$ Centre for Addictions Research of BC, University of Victoria, Victoria, British Columbia, Canada \\ ${ }^{2}$ British Columbia Centre of Excellence for Women's Health, Vancouver, British Columbia, Canada \\ ${ }^{3}$ British Columbia Centre of Excellence for Women's Health, CanFASD Research Network, Vancouver, British Columbia, Canada \\ ${ }^{4}$ CanFASD Research Network, Vancouver, British Columbia, Canada
}

\begin{abstract}
Aims and Method: Alcohol warning labels are one way of influencing alcohol consumption in pregnancy and thereby preventing Fetal Alcohol Spectrum Disorder (FASD). This scoping review describes the literature on the influence of alcohol warning labels (AWLs) for changing attitudes and behavior related to alcohol use in pregnancy; draws on the larger literature related to effectiveness of AWLs which may have relevance to FASD prevention; and situates AWLs within a continuum of strategies to prevent FASD.

Findings: Our review of the published literature suggests that while AWLs are popular with the public, their effectiveness for changing drinking behavior is limited. Available research suggests that for maximum effect, AWLs should speak clearly about the consequences of alcohol consumption and should also be coordinated and integrated with other, broader social messaging campaigns. Use of AWLs related to alcohol and pregnancy must be carefully considered; their messaging has the most influence on low-risk drinkers, and to date they have not been shown to change the drinking behavior of those who drink heavily or binge during pregnancy. However, AWLs have been shown to stimulate conversations about alcohol consumption and may play a role in shifting social norms to reduce risks.

Conclusions: Multiple measures are required to increase societal awareness of the risks of drinking in pregnancy, influence alcohol consumption by pregnant women, and improve the quality of support for women with alcohol and related health and social problems.
\end{abstract}

Fetal Alcohol Spectrum Disorder (FASD) represents a constellation of adverse effects resulting from prenatal exposure to alcohol. It is the leading known cause of developmental disability in Canada and has lifelong consequences. Since it is estimated that over 350,000 Canadians are impacted by FASD, and that 3,000 to 4,000 new cases are added yearly, the need for evidence-based prevention interventions is critical.

Alcohol Warning Labels (AWLs) have been used by a number of countries as a way of trying to prevent FASD by encouraging women to abstain from alcohol consumption during pregnancy. The effectiveness of warning labels for cessation or reduction of maternal alcohol use has not been determined for risky drinkers, however, so their use remains controversial.
Several jurisdictions, including the United States, France, Russia, South Africa, and the Yukon and Northwest Territories in Canada, have regulations requiring warning labels related to drinking during pregnancy and/or other risks. Other countries, such as the United Kingdom, have chosen to work with industry to encourage the voluntary placement of consumer information and health warning labels (see Table 1).

One of the main arguments against implementing mandatory AWLs is that it is unclear how much evidence supports their effectiveness for reducing risky alcohol consumption. This review was undertaken to summarize the published literature related to the effectiveness of AWLs for preventing FASD. 
Table 1

Alcohol health warning labels addressing pregnancy, c. February 2010

\begin{tabular}{|c|c|c|c|}
\hline Country & $\begin{array}{l}\text { Mandate/ } \\
\text { Voluntary }\end{array}$ & Warning Label Text/Guidance & Other Warning Label Requirements, Source \\
\hline China & Voluntary & $\begin{array}{l}\text { Recommended: } \\
\text { "Overdrinking is harmful to heath" } \\
\text { "Pregnant women and children shall } \\
\text { not drink" }\end{array}$ & $\begin{array}{l}\text { See GB10344-2005: General Standard for the Labeling of Prepackaged } \\
\text { Alcoholic Beverages <http://www.szciq.gov.cn/WebEditor/ } \\
\text { uploadfile/20080814085907230.pdf> }\end{array}$ \\
\hline France & Mandated & $\begin{array}{l}\text { "Drinking alcoholic beverages during } \\
\text { pregnancy, even in small quantities, } \\
\text { can have grave/serious consequences } \\
\text { for the health of the baby” } \\
\text { OR use the government-issued symbol } \\
\text { showing a diagonal line being } \\
\text { superimposed on an image of a } \\
\text { pregnant woman holding a glass }\end{array}$ & $\begin{array}{l}\text { Packaging of all beverage alcohol products sold or distributed (including } \\
\text { for free, as promotions) in France must have at least one of the two } \\
\text { health messages recommending that pregnant women do not drink } \\
\text { alcohol. } \\
\text { The health message must appear in the same visual field as the } \\
\text { obligatory labeling on the alcohol content. } \\
\text { The warning message must be written on a contrasting background in a } \\
\text { manner that is visible, reliable, clear, understandable, and indelible. } \\
\text { See <http://www.vins-bourgogne.fr/connaitre/la-terre-de-bourgogne/l- } \\
\text { etiquetage/gallery_files/site/321/360.pdf> }\end{array}$ \\
\hline Japan & Voluntary & $\begin{array}{l}\text { "Drinking alcohol during pregnancy or } \\
\text { nursing may adversely affect the } \\
\text { development of your fetus or child" } \\
\text { "Be careful not to drink in excess" } \\
\text { "Drink in moderation" }\end{array}$ & $\begin{array}{l}\text { Displayed in an easy-to-read location on the container, using uniform } \\
\text { Japanese font at least } 6 \text { points in size. } \\
\text { See Self-Regulatory Code of Advertisement Practices and Container } \\
\text { Labeling for Alcoholic Beverages < http://www.youshu- } \\
\text { yunyu.org/english04/index.html> }\end{array}$ \\
\hline $\begin{array}{l}\text { Russian } \\
\text { Federation }\end{array}$ & Mandated & $\begin{array}{l}\text { "Alcohol is not for children and } \\
\text { teenagers up to age 18, pregnant and } \\
\text { nursing women, or persons with } \\
\text { diseases of the central nervous system, } \\
\text { kidneys, liver, and other digestive } \\
\text { organs" }\end{array}$ & $\begin{array}{l}\text { Must label wine and vodka and other spirits. } \\
\text { Ministry of Health Decree No. 49, dated January 19, } 2007 \text { as referenced } \\
\text { in this document < http://www.calwinexport.com/files/Russia\%20- } \\
\text { \%20Requirements\%20for\%20Exporting\%20to\%20Russia\%202007.pdf }\end{array}$ \\
\hline $\begin{array}{l}\text { South } \\
\text { Africa }\end{array}$ & Mandated & $\begin{array}{l}\text { "Alcohol reduces driving ability; don’t } \\
\text { drink and drive” } \\
\text { "Don’t drink and walk on the road; you } \\
\text { may be killed” } \\
\text { "Alcohol increases your risk of } \\
\text { personal injuries” } \\
\text { "Alcohol is a major cause of violence } \\
\text { and crime” } \\
\text { "Alcohol abuse is dangerous to your } \\
\text { health” } \\
\text { "Alcohol is addictive” } \\
\text { "Drinking during pregnancy can be } \\
\text { harmful to your unborn baby” }\end{array}$ & $\begin{array}{l}\text { (1) Container labels for alcohol beverages must contain at least one of } \\
\text { the [seven] health messages. } \\
\text { (2) A health message referred to in sub-regulation shall (i) be visible, } \\
\text { legible, and indelible and the legibility thereof shall not be affected by } \\
\text { any other matter, printed or otherwise; (ii) be on a space specifically } \\
\text { devoted for it, which must be at least one-eighth of the total size of the } \\
\text { container label; and (iii) be in black on a white background. } \\
\text { See Foodstuffs, Cosmetics and Disinfectants Act, 1972-Regulations } \\
\text { Relating to Health Messages on Container Labels of Alcoholic } \\
\text { Beverages, } 24 \text { August } 2007 \\
<\text { http://www.info.gov.za/view/DownloadFileAction?id=72307 > }\end{array}$ \\
\hline $\begin{array}{l}\text { United } \\
\text { States }\end{array}$ & Mandated & $\begin{array}{l}\text { "GOVERNMENT WARNING: } \\
\text { (1) According to the Surgeon General, } \\
\text { women should not drink alcoholic } \\
\text { beverages during pregnancy because of } \\
\text { the risk of birth defects. } \\
\text { (2) Consumption of alcoholic } \\
\text { beverages impairs your ability to drive } \\
\text { a car or operate machinery, and may } \\
\text { cause health problems" }\end{array}$ & $\begin{array}{l}\text { The health warning statement must appear on the brand label or separate } \\
\text { front label, or on a back or side label, separate and apart from all other } \\
\text { information. } \\
\text { It must be readily legible under ordinary conditions, and must appear on } \\
\text { a contrasting background. Furthermore, labels bearing the warning must } \\
\text { be firmly affixed to the container. } \\
\text { The words ' GOVERNMENT WARNING”' must appear in capital } \\
\text { letters and in bold type. } \\
\text { Minimum type size is specified for containers of various sizes. } \\
\text { See Title 27: Alcohol, Tobacco and Firearms. Part 16-Alcoholic } \\
\text { Beverage Health Warning Statement, § } 16.21 \text { Mandatory Label } \\
\text { Information } \\
<\text { http://law.justia.com/us/cfr/title27/27- } \\
\text { 1.0.1.1.12.html\#27:1.0.1.1.12.3.45.2> }\end{array}$ \\
\hline
\end{tabular}




\section{Methods}

A scan of academic and web-based literature related to pregnancy and alcohol warning labels was undertaken by researchers at the British Columbia Centre of Excellence for Women's Health between September and November, 2012. The databases searched included Academic Search Premier, Bibliography of Native North Americans, CINAHL, Health Source: Nursing/Academic Edition, PsycINFO, MEDLINE, Social Work Abstracts, and Women's Studies International. Search terms utilized: alcohol warning labels and pregnancy. Inclusion criteria: articles published after 1990, in the English language, relevant to Canadian alcohol policy context.

Eighteen articles related to pregnancy and alcohol warning labels were retrieved using the inclusion criteria. A table of these articles is included as Table 2. These articles are considered in the light of criteria from the larger literature for effectiveness of alcohol warning labels in influencing attitudes and behavior of drinkers.

Table 2

Retrieved studies related to influence of alcohol warning labels on alcohol consumption in pregnancy

\begin{tabular}{|c|c|c|c|c|c|}
\hline Author(s) & Year & Title & $\begin{array}{l}\text { Country } \\
\text { of Study }\end{array}$ & Aim of Study & Study Design \\
\hline $\begin{array}{l}\text { Mazis, } \\
\text { Michael B.; } \\
\text { Morris, } \\
\text { Louis A.; } \\
\text { Swasy, John } \\
\text { L. }\end{array}$ & 1991 & $\begin{array}{l}\text { An evaluation } \\
\text { of the alcohol } \\
\text { warning label: } \\
\text { Initial survey } \\
\text { results }\end{array}$ & $\begin{array}{l}\text { United } \\
\text { States }\end{array}$ & $\begin{array}{l}\text { To assess the impact } \\
\text { of alcoholic } \\
\text { beverage warning } \\
\text { labels through } \\
\text { national surveys } \\
\text { conducted in May } \\
1989 \text { and May } 1990\end{array}$ & $\begin{array}{l}\text { National surveys were } \\
\text { conducted in May } 1989 \\
\text { and May 1990. A } \\
\text { proportionate stratified } \\
\text { sampling design, using } \\
\text { random-digit dialing, was } \\
\text { employed in both } \\
\text { surveys. }\end{array}$ \\
\hline
\end{tabular}

Kaskutas,

Lee;

Greenfield,

Thomas K.
1992

First effects of on alcoholic

beverage

containers
United

States

To assess who has seen these labels and respondents' reported changes in relevant knowledge, attitudes and behavior
Hankin, J.R.;

Sloan, James

J.; Firestone,

Ira J.; Ager,

Joel W.;

Sokol,

Robert J.;

Martier,

Susan S.;

Townsend,

Joyce.

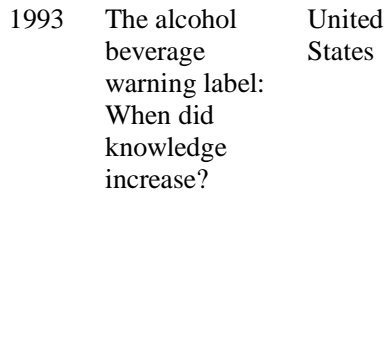

United
States
To examine the change in knowledge of the existence of the US alcohol warning label among a sample of high-risk, lower- socioeconomic-status African-American women seeking prenatal care at an inner-city clinic.

Random samples of the adult general population of the US were interviewed by phone six months prior to and six months after the 1989 implementation of legislation regarding the AWL $(N=2006$ and 2000, respectively).

African-American women $(N=5,169)$ seeking care at Hutzel Hospital prenatal clinic in Detroit, MI, from May 22, 1989 to May 31, 1992, were interviewed prior to their seeing a physician.
Primary Outcomes

After implementation of the AWL, a slight increase in the public's perception of the risk associated with consuming alcohol (35 percent of the sample responded that alcoholic beverage containers were "very likely" or "somewhat likely" to have warnings).

11 percent of the sample were able to identify the specific pregnancy hazard warnings with awareness levels highest among younger adults and "heavy" alcohol consumers.

Six months after introduction

AWL:

- over one-fifth of the respondents reported having seen the labels;

- heavy drinkers, and young men at risk for drunk driving, were more likely to report seeing the warnings;

- no significant changes in knowledge of the health risks were detected;

- respondents who saw the warning labels related to the hazards of drinking and driving and of drinking during pregnancy were significantly more likely to report behaviors indicative of heightened awareness of, and caution regarding, these warnings.

A significant increase in awareness of the AWL among the subjects beginning in March 1990.

Women who consumed wine coolers and beer (predominantly), and those under age 30 , were more likely to know about the AWL. 


\begin{tabular}{|c|c|c|c|c|c|c|}
\hline Author(s) & Year & Title & $\begin{array}{l}\text { Country } \\
\text { of Study }\end{array}$ & Aim of Study & Study Design & Primary Outcomes \\
\hline $\begin{array}{l}\text { Hankin, Janet } \\
\text { R.; Firestone, } \\
\text { Ira J.; Sloan, } \\
\text { James J.; Ager, } \\
\text { Joel W.; } \\
\text { Goodman, } \\
\text { Allen C.; } \\
\text { Sokol, Robert } \\
\text { J.; Martier, } \\
\text { Susan S. }\end{array}$ & 1993 & $\begin{array}{l}\text { The impact of } \\
\text { the alcohol } \\
\text { warning label } \\
\text { on drinking } \\
\text { during } \\
\text { pregnancy }\end{array}$ & $\begin{array}{l}\text { United } \\
\text { States }\end{array}$ & $\begin{array}{l}\text { To ascertain whether } \\
\text { drinking by pregnant } \\
\text { women had } \\
\text { decreased since the } \\
\text { implementation of } \\
\text { the alcoholic } \\
\text { beverage warning } \\
\text { label }\end{array}$ & $\begin{array}{l}\text { The reported drinking of } \\
4,379 \text { pregnant black } \\
\text { women who sought } \\
\text { prenatal care in an inner- } \\
\text { city clinic of Detroit, } \\
\text { Michigan between May } \\
\text { 22, } 1989 \text { and September } \\
\text { 30,1991 was examined. }\end{array}$ & $\begin{array}{l}\text { AWL had a differential effect on } \\
\text { lighter versus heavier drinkers: } \\
\text { - six months post } \\
\text { implementation of the AWL } \\
\text { (June 1, 1990), lighter drinkers } \\
\text { decreased their drinking during } \\
\text { pregnancy by a small but } \\
\text { statistically significant amount. } \\
\text { - pregnant risky drinkers did not } \\
\text { significantly change their } \\
\text { alcohol consumption. }\end{array}$ \\
\hline
\end{tabular}

Hankin,

Janet R.;

Sloan, James

J.; Firestone,

Ira J.; Ager,

Joel W.
1993 A time series United To test the analysis of the States hypothesis that the impact of the alcohol warning label on antenatal drinking

alcohol warning

label introduced in antenatal drinking
Barrett, M.

E.; Wong, F.

Y.; McKay,

D. R.
1993

Self-report
alcohol use
among wom

among women

of child-

bearing age

and their

knowledge of

alcohol

warning labels

and signs
Glascoff,

Mary A.;

Felts, W.

Michael
The awarenes

level of

pregnant

women of

alcoholic

beverage

health

warning labels
1988 had decreased

United

States

To examine the prevalence of selfreported alcohol use among women of childbearing age and their ability to recall information about pregnancy risk contained in warning labels on alcoholic beverage containers and warning signs posted in places where liquor is sold

United States

To survey pregnant women attending rural prenatal clinics on their awareness of warning labels on different products
African - American pregnant women $(n=$ 12,026) completed measures of periconceptual and antenatal drinking. A time series was constructed using the monthly means of antenatal alcohol per day for the five years under study.

Illinois-based adults ( $n=$ 4987) were surveyed by phone in spring and summer of 1990 , including 1,515 women of childbearing age (18 through 45 years old). The telephone survey was conducted with using a dual-frame procedure (including contact by both randomdigit dialing and by listed residential telephone numbers).

Poststratification weighting was done using estimates of age, ethnic, and sex groups to approximate the 1990 adult population of Illinois.

Pregnant women $(N=$ 140) attending prenatal clinics at rural health departments were interviewed on their awareness of which of 12 products (including beer liquor and wine) were "not good to use" during pregnancy and their knowledge of which products carried a warning label to that effect, as well as their knowledge of how a troubled pregnancy or a sick newborn could be related to use of any of the 12 products.
A lag of 7 months was found in the impact of the AWL.

Antenatal drinking decreased as of June 1990, but this decrease was small and did not impact on the heaviest of drinkers.

Pregnant women were significantly less likely than nonpregnant women to report using alcohol in the past 30 days. Approximately one-quarter of all women were able to recall information about pregnancy risk contained in warning labels and signs.

Alcohol warning labels and signs seemed to be reaching a minority of women; regardless of sociodemographic status.

A lack of awareness of AWLs was found, as compared with warnings related to other products.

Respondents indicated a high measure of knowledge that alcohol is not recommended during pregnancy.

No relationships between label awareness and age, race and other factors were found. 


\begin{tabular}{|c|c|c|c|c|}
\hline Author(s) & Year & Title & $\begin{array}{l}\text { Country } \\
\text { of Study }\end{array}$ & Aim of Study \\
\hline $\begin{array}{l}\text { Kaskutas, L. } \\
\text { A.; Graves, } \\
\text { K. }\end{array}$ & 1994 & $\begin{array}{l}\text { Relationship } \\
\text { between } \\
\text { cumulative } \\
\text { exposure to } \\
\text { health } \\
\text { messages and } \\
\text { awareness and } \\
\text { behavior- } \\
\text { related } \\
\text { drinking } \\
\text { during } \\
\text { pregnancy }\end{array}$ & $\begin{array}{l}\text { United } \\
\text { States }\end{array}$ & $\begin{array}{l}\text { To describe the } \\
\text { relationship between } \\
\text { exposure to multiple } \\
\text { sources of health } \\
\text { messages about the } \\
\text { risk of drinking } \\
\text { during pregnancy, } \\
\text { and respondents' } \\
\text { awareness and } \\
\text { behavior related to } \\
\text { this risk }\end{array}$ \\
\hline
\end{tabular}

\begin{tabular}{|c|c|}
\hline Study Design & Primary Outcomes \\
\hline $\begin{array}{l}\text { vational study } \\
\text { telephone interview } \\
\text { n the impact of } \\
\text { ure to a message } \\
\text { drinking in } \\
\text { ancy via a } \\
\text { nment warning on } \\
\text { olic beverage } \\
\text { iners, warning } \\
\text { rs in restaurants and } \\
\text { and media } \\
\text { tisements. The } \\
\text { cts were } \\
\text { sentative nationwide } \\
\text { les of adults } \\
\text { iewed in } 1990 \text { ( } n= \\
\text { ) and } 1991 \text { ( } n= \\
\text { ), with response } \\
\text { of } 64 \% \text { and } 62 \% \text {, } \\
\text { ctively. Multivariate } \\
\text { ic regression } \\
\text { ls were used. } \\
\text { retation of findings } \\
\text { nited due to } \\
\text { ndent bias in } \\
\text { ol consumption, }\end{array}$ & $\begin{array}{l}\text { Findings support the public } \\
\text { health approach of implementing } \\
\text { multi-faceted strategies to } \\
\text { maximize risk reduction } \\
\text { interventions: } \\
\text { - respondents exposed to one, } \\
\text { two, and three different } \\
\text { message sources were more } \\
\text { likely to converse about } \\
\text { drinking during pregnancy } \\
\text { than those exposed to no } \\
\text { messages (odds ratio = 2.6, } \\
\text { 3.8, and 4.1, respectively); } \\
\text { - reduced alcohol consumption } \\
\text { due to health concerns was } \\
\text { associated with exposure to } \\
\text { two and three different sources } \\
\text { (odds ratio = } 1.6 \text { and } 2.0 \text {, } \\
\text { respectively). } \\
\text { - among women aged } 18 \text { to } 40 \text {, a } \\
\text { similar relationship was found } \\
\text { for conversations, but it was } \\
\text { only among those seeing all } \\
\text { three message types that a } \\
\text { reduction in consumption was } \\
\text { observed (odds ratio = } 2.8 \text { ). }\end{array}$ \\
\hline
\end{tabular}

exposure, and the crosssectional nature of the data employed.

Changes in the level of awareness were examined among 7,334 inner-city AfricanAmerican women (mean age 23.8 years) seeking prenatal care between May 1989 and June 1993.

Examined trends in monthly means of antenatal drinking scores (alcohol consumption adjusted for weeks' gestation, age, parity and periconceptional drinking) using time series analysis. warning label 10,107 multiparae and 7,349 nulliparae inner-city AfricanAmerican pregnant women (mean age 23.7 years) seen between 1986 and 1993 at one antenatal clinic

Hankin, Janet R.; Sloan, James J.; Sokol, Robert J.
1998 The modest United impact of the States alcohol beverage warning label on drinking during pregnancy
To examine the impact of the alcohol warning label on inpregnancy drinking by 21,127 AfricanAmerican women between 1986 and 1995
A time series analysis, controlling for patient characteristics and unemployment rate of prenatal drinking by 21,127 African-American women between 19861995.
Level of awareness of AWLs continued to increase through 1992 and then leveled off. The authors concluded that the upper limit of awareness in this population had been reached. Women over the age of 29 were less likely to know about the warning label.

Heavier drinkers were 1.25 times more likely to be aware of the label.

$30 \%$ of drinkers who were not aware of the label, drank both at conception and during the antenatal period.

Reported drinking by nulliparae subjects began to show a significant decline in 1990, seven months after the implementation of the AWL.

Multiparae subjects showed no change in reported drinking behavior post introduction of the AWL.

The label had a significant, modest impact on drinking. Authors suggest that the label may have had a short-term effect, which is consistent with the notion that public health messages lose their impact over time and that more intensive 


\begin{tabular}{|c|c|c|c|c|c|}
\hline Author(s) & Year & Title & $\begin{array}{l}\text { Country } \\
\text { of Study }\end{array}$ & Aim of Study & Study Design \\
\hline & & $\begin{array}{l}\text { among a } \\
\text { sample of } \\
\text { African- } \\
\text { American } \\
\text { women }\end{array}$ & & & \\
\hline $\begin{array}{l}\text { Hankin, } \\
\text { Janet R. }\end{array}$ & 1998 & $\begin{array}{l}\text { Label } \\
\text { exposure and } \\
\text { recall among } \\
\text { Detroit } \\
\text { Metropolitan } \\
\text { women }\end{array}$ & $\begin{array}{l}\text { United } \\
\text { States }\end{array}$ & $\begin{array}{l}\text { To examine } \\
\text { exposure to the } \\
\text { alcoholic beverage } \\
\text { warning label among } \\
\text { a sample of } 1,107 \\
\text { Detroit-area women } \\
\text { in } 1995\end{array}$ & $\begin{array}{l}\text { The analysis was } \\
\text { conducted at two levels: } \\
\text { 1) What are the } \\
\text { predictors of label } \\
\text { exposure? } \\
\text { 2) Following label } \\
\text { exposure, what are the } \\
\text { predictors of correct } \\
\text { knowledge of the } \\
\text { warning message? }\end{array}$ \\
\hline
\end{tabular}

Greenfield, Thomas K.; Kaskutas, Lee Ann
Kaskutas, L. 1998 Reach and

A.;

Greenfield,

T.; Lee, M.

E.; Cote, J. exposure to alcohol

warning label messages and their impacts: Evidence from diffusion analysis
United To focus on the time States course of exposure levels in the U.S. for a period of approximately five years following the 1989 introduction of the mandated label, examining long-term penetration in various important subgroups defined by demographics and drinking-related variables

\section{effects of}

health

messages on

drinking

during

pregnancy
United

States

To investigate the relationships between alcohol consumption and exposure to four sources of health messages in a general population sample of pregnant women. Sources
Analyses used data collected from large annual cross-sectional telephone surveys of probability samples of U.S. adults, 1989 through 1991 and in 1993 and 1994 (total $N \approx 8,000$ ). Data from current drinkers $(n=5,494)$ were used in a diffusion analysis, examining penetration, overall and in subgroups, of two label messages, warning against drinking when pregnant and driving while impaired by alcohol. Curve-fitting techniques were used to examine curve forms, time trends and

asymptotes, to estimate maximal penetration levels in target groups (younger men and women of child-bearing age, and heavy quantity drinkers).

A five-year crosssectional U.S. national survey and a two-year longitudinal study of women of childbearing age (18-40 yrs).
Primary Outcomes

interventions are needed to support women to reduce drinking in pregnancy.

Results suggest that exposure to the warning label is limited among certain subgroups of women, and additional prevention efforts are needed to warn these women of the dangers

of alcohol use:

- thirty-nine percent of all women (59\% of drinkers) reported seeing the warning label over the year;

- age and frequency of drinking were predictors of label exposure;

- $25 \%$ of women who saw the AWL could correctly identify all three messages on the label;

- women were less likely to know the wording on the warning label if they were older, infrequent drinkers, and/or did not binge drink.

Exposure rose rapidly then levelled out by 1994, suggesting limits for the warning label policy and its capacity to remind the public of alcohol health risks.

Sixty-nine percent of male heavy drinkers and $65 \%$ of female heavy drinkers reported seeing the AWL in the prior 12 months (adjusted with curve fitting). Specific message exposure shows similar patterns: by $1994,56 \%$ of U.S. female drinkers $18-40$ remembered the pregnancy warning, while $38 \%$ of men $18-$ 40 recalled the drunk driving message.

In all years post implementation of the AWL, maximum quantity consumed and younger age were important predictors of exposure.

The vast majority of drinking women (80 percent) decrease their alcohol use during pregnancy, with 61 percent of drinkers abstaining completely. Pregnant women who do drink consume low quantities of alcohol, with only 4 percent reporting consuming more than 3 drinks in a single day. 


\begin{tabular}{|c|c|c|c|c|c|c|}
\hline Author(s) & Year & Title & $\begin{array}{l}\text { Country } \\
\text { of Study }\end{array}$ & Aim of Study & Study Design & Primary Outcomes \\
\hline & & & & $\begin{array}{l}\text { included alcohol } \\
\text { beverage container } \\
\text { labels, point-of-sale } \\
\text { signs, } \\
\text { advertisements, and } \\
\text { personal } \\
\text { conversations }\end{array}$ & & $\begin{array}{l}\text { Message exposure varied greatly } \\
\text { by source, from } 84 \text { percent } \\
\text { reporting conversations about the } \\
\text { dangers of drinking during } \\
\text { pregnancy to } 17 \text { percent who had } \\
\text { seen a point-of-sale poster. } \\
\text { While an increase was found in } \\
\text { the proportion of pregnant } \\
\text { women exposed to AWL } \\
\text { messages about drinking in } \\
\text { pregnancy, a significant decline } \\
\text { in the proportion exposed to } \\
\text { advertisements and to } \\
\text { conversations about the risk was } \\
\text { also found. } \\
\text { No relationship was found } \\
\text { between AWL exposure and } \\
\text { drinking by pregnant women. } \\
\text { Changes in drinking during } \\
\text { pregnancy were not found to be } \\
\text { associated with exposure to any } \\
\text { of the assessed messages (labels, } \\
\text { posters, advertisements, and } \\
\text { conversations). }\end{array}$ \\
\hline $\begin{array}{l}\text { Greenfield, } \\
\text { Thomas K.; } \\
\text { Graves, } \\
\text { Karen L.; } \\
\text { Kaskutas, } \\
\text { Lee A. }\end{array}$ & 1999 & $\begin{array}{l}\text { Long-term } \\
\text { effects of } \\
\text { alcohol } \\
\text { warning } \\
\text { labels: } \\
\text { Findings from } \\
\text { a comparison } \\
\text { of the United } \\
\text { States and } \\
\text { Ontario, } \\
\text { Canada }\end{array}$ & $\begin{array}{l}\text { United } \\
\text { States } \\
\text { and } \\
\text { Canada }\end{array}$ & $\begin{array}{l}\text { To evaluate the } \\
\text { impact of the } \\
\text { introduction of a } \\
\text { health warning label } \\
\text { on alcoholic } \\
\text { beverage containers }\end{array}$ & $\begin{array}{l}\text { US national probability } \\
\text { sample cross-sectional } \\
\text { surveys of adults ( } 18 \text { and } \\
\text { over) were conducted by } \\
\text { phone in the summer of } \\
1990 \text { and } 1991 \text {, and } 1993 \\
\text { and } 1994 \text {. In the same } \\
\text { years surveys were } \\
\text { conducted in Ontario, to } \\
\text { serve as a no-intervention } \\
\text { reference site. In the US, } \\
\text { sample sizes were } 2006 \text {, } \\
2017,1026 \text { and } 1016 \text { in } \\
\text { the respective survey } \\
\text { years, Ontario surveys } \\
\text { included the same key } \\
\text { variables and interviewed } \\
1045,1028,1022 \text { and } \\
1028 \text { adults respectively. }\end{array}$ & $\begin{array}{l}\text { Exposure to AWL was weaker } \\
\text { for all years in the reference site. } \\
\text { The proportion reporting } \\
\text { conversations about drinking } \\
\text { during pregnancy was higher in } \\
\text { both sites among people who had } \\
\text { seen labels. }\end{array}$ \\
\hline $\begin{array}{l}\text { Guillemont, } \\
\text { J.; Léon, C. }\end{array}$ & 2008 & $\begin{array}{l}\text { Alcool et } \\
\text { grossesse: } \\
\text { connaissances } \\
\text { du grand } \\
\text { public en } 2007 \\
\text { et évolutions } \\
\text { en trois ans } \\
\text { [Alcohol and } \\
\text { pregnancy: } \\
\text { Public } \\
\text { knowledge in } \\
2007 \text { and its } \\
\text { changes over } \\
\text { three years] }\end{array}$ & France & $\begin{array}{l}\text { To measure the } \\
\text { subsequent changes } \\
\text { following a public } \\
\text { campaign in France } \\
\text { of the general } \\
\text { public's knowledge } \\
\text { about the issue of } \\
\text { alcohol consumption } \\
\text { during pregnancy. }\end{array}$ & $\begin{array}{l}\text { Two telephone surveys } \\
\text { were conducted in } 2004 \\
\text { and } 2007 \text {, with two } \\
\text { independent samples } \\
\text { representative of the } \\
\text { French population aged } \\
15 \text { and over. These } \\
\text { samples ( } n=1,003 \text { and } n \\
=1,006 \text {, respectively) } \\
\text { were constructed } \\
\text { according to the quota } \\
\text { method. }\end{array}$ & $\begin{array}{l}\text { The recommendation to not drink } \\
\text { alcohol during pregnancy was } \\
\text { better known in } 2007 \text { than in } \\
2004 \text { ( } 87 \% \text { vs. } 82 \% \text { ). } \\
\text { In } 2007,30 \% \text { believed that the } \\
\text { risk to the fetus begins with the } \\
\text { first glass, up from } 25 \% \text { in } 2004 \text {. } \\
\text { In } 2007,27 \% \text { (up from } 22 \% \text { in } \\
2004 \text { ) believed the risk of alcohol } \\
\text { consumption is the same } \\
\text { throughout pregnancy. } \\
\text { In both years, one in two } \\
\text { respondents felt that drinking } \\
\text { beer or wine in pregnancy is as } \\
\text { dangerous as drinking hard } \\
\text { liquor. }\end{array}$ \\
\hline
\end{tabular}




\begin{tabular}{|c|c|c|c|c|c|c|}
\hline Author(s) & Year & Title & $\begin{array}{l}\text { Country } \\
\text { of Study }\end{array}$ & Aim of Study & Study Design & Primary Outcomes \\
\hline $\begin{array}{l}\text { Parackal, } \\
\text { Sherly M.; } \\
\text { Parackal, } \\
\text { Mathew K.; } \\
\text { Harraway, } \\
\text { John A.; } \\
\text { Ferguson, } \\
\text { Elaine L. }\end{array}$ & 2009 & $\begin{array}{l}\text { Opinions of } \\
\text { non-pregnant } \\
\text { New Zealand } \\
\text { women aged } \\
16-40 \text { years } \\
\text { about the } \\
\text { safety of } \\
\text { alcohol } \\
\text { consumption } \\
\text { during } \\
\text { pregnancy }\end{array}$ & $\begin{array}{l}\text { New } \\
\text { Zealand }\end{array}$ & $\begin{array}{l}\text { To assess the } \\
\text { opinions of New } \\
\text { Zealand women on } \\
\text { the safety of alcohol } \\
\text { consumption in } \\
\text { pregnancy, and the } \\
\text { sociodemographic } \\
\text { and lifestyle factors } \\
\text { associated with these } \\
\text { opinions }\end{array}$ & $\begin{array}{l}\text { A nationwide, cross- } \\
\text { sectional survey was } \\
\text { conducted in } 2005 \text { on a } \\
\text { random sample of } 1,109 \\
\text { non-pregnant women } \\
\text { aged } 16-40 \text { years. Data } \\
\text { were collected via an } \\
\text { interviewer-administered } \\
\text { questionnaire using a } \\
\text { web-assisted telephone } \\
\text { interviewing system. }\end{array}$ & $\begin{array}{l}\text { An association of drinking style } \\
\text { with opinions about the safety of } \\
\text { alcohol consumption in } \\
\text { pregnancy was found: } \\
\text { - overall, } 44 \% \text { ( } 95 \% \text { confidence } \\
\text { interval } 41-47 \text { ) of women } \\
\text { surveyed indicated that no } \\
\text { alcohol is safe in pregnancy; } \\
\text { - those who stated that no } \\
\text { alcohol is safe in pregnancy } \\
\text { were more likely to be of } \\
\text { Pacific Island ethnicity ( } P< \\
\text { 0.05) and abstainers ( } P< \\
\text { 0.001); } \\
\text { - heavier drinkers were more } \\
\text { likely to be of the opinion that } \\
\text { "more than one standard } \\
\text { drink" of alcohol is safe on a } \\
\text { typical drinking day during } \\
\text { pregnancy ( } P<0.001 \text { ). }\end{array}$ \\
\hline $\begin{array}{l}\text { Parackal, } \\
\text { Sherly M.; } \\
\text { Parackal, } \\
\text { Mathew K.; } \\
\text { Harraway, } \\
\text { John A. }\end{array}$ & 2010 & $\begin{array}{l}\text { Warning } \\
\text { labels on } \\
\text { alcohol } \\
\text { containers as a } \\
\text { source of } \\
\text { information } \\
\text { on alcohol } \\
\text { consumption } \\
\text { in pregnancy } \\
\text { among New } \\
\text { Zealand } \\
\text { women }\end{array}$ & $\begin{array}{l}\text { New } \\
\text { Zealand }\end{array}$ & $\begin{array}{l}\text { To report the rating } \\
\text { of a national sample } \\
\text { of } 16-40 \text {-year-old } \\
\text { non-pregnant New } \\
\text { Zealand women on a } \\
\text { warning label on } \\
\text { alcohol containers as } \\
\text { a source of } \\
\text { information about } \\
\text { risks associated with } \\
\text { alcohol consumption } \\
\text { in pregnancy }\end{array}$ & $\begin{array}{l}\text { A nationwide, cross- } \\
\text { sectional survey was } \\
\text { conducted in } 2005 \text { on a } \\
\text { random sample of } 1,129 \\
\text { non-pregnant women } \\
\text { aged 16-40 years. Data } \\
\text { were collected via an } \\
\text { interviewer-administered } \\
\text { questionnaire using a } \\
\text { Web-assisted telephone } \\
\text { interviewing system. } \\
\text { Overall, the survey } \\
\text { achieved a response rate } \\
\text { of } 65 \% \text {. }\end{array}$ & $\begin{array}{l}\text { Over half of the women surveyed } \\
\text { (53\%; 95\% CI 50.2-56.0) gave a } \\
\text { high rating for AWL as a source } \\
\text { of info on alcohol us in } \\
\text { pregnancy. } \\
\text { Younger women (below } 30 \text { years } \\
\text { of age) and those of non- } \\
\text { European ethnicity were more } \\
\text { likely to give a high rating for } \\
\text { AWL a source of info compared } \\
\text { with older women and European } \\
\text { women. } \\
\text { Thus AWLs may increase } \\
\text { awareness of the risks associated } \\
\text { with alcohol consumption in } \\
\text { pregnancy among at-risk } \\
\text { drinkers, yet to achieve } \\
\text { behavioral change other } \\
\text { complementary prevention } \\
\text { approaches may be needed. }\end{array}$ \\
\hline
\end{tabular}

\section{Results}

In this article we report on measures of effectiveness of AWLs in general, on measures of their effectiveness specifically in influencing the drinking behavior of pregnant women where available, and, where such measures are unavailable, on their potential for influencing the alcohol consumption of pregnant women.

A variety of approaches have been used to try to prevent alcohol consumption during pregnancy. Some of these approaches, such as AWLs and mass media public service announcements, are forms of universal prevention and are designed to increase the general public's knowledge about the dangers of consuming alcohol while pregnant.

Only a few countries that have implemented AWLs have systematically evaluated their effectiveness for raising awareness, changing attitudes and affecting drinking behaviors, and the evidence that does exist is mixed. For example, there is some evidence suggesting that AWLs are effective for persuading people to try to prevent others from driving while drunk (Tam \& Greenfield, 2010). Other studies report that, while AWLs are an increasingly popular alcohol policy initiative, they may be ineffective for changing drinking behavior (Wilkinson \& Room, 2009). Given the limited evidence for their effectiveness in changing attitudes and behavior, any proposal to introduce AWLs as a core strategy to address maternal alcohol use should be carefully considered.

Criteria for assessing effectiveness: In a metaanalysis investigating the effectiveness of health warning labels for a variety of consumer goods including alcohol, Argo \& Main (2004) state that effectiveness can be assessed by considering the dimensions of attention, comprehension, recall, judgment, and behavioral compliance. These dimensions comprise a cognitive- 
behavioral process whereby individuals are made consciously aware of an issue via a warning label, see and understand the warning as conveyed, are able to accurately recall the message, allow the message to shift their judgments and beliefs, and allow these changes to affect their behavioral choices. Based on this framework, effective AWLs consist of a signal word or phrase to attract attention, identification of the hazard, explanation of consequences if exposed to the hazard, and directives for avoiding the hazard (Eurocare, 2011).

Do alcohol warning labels attract attention? Research on the American AWL suggests that they are noticed by only a minority of drinkers, with awareness increasing with frequency of drinking: heavy and frequent drinkers report higher levels of awareness than infrequent drinkers (Greenfield, 1997; Hankin et al., 1996, Kaskutus \& Greenfield, 1992). Based on the observed dose-response effect, Kaskutas and Greenfield (1997) documented that the AWL messages mandated in 1989 in the U.S. were reaching the main target audiences: young adults, males, and heavier alcohol consumers.

The overall noticeability of AWLs depends on a number of factors. Experience with alcohol and tobacco warning labels suggests that consumer attention is maximized and sustained when the warnings are larger, more colorful, and contain graphics or images (including "graphic" images of harm), and when warnings are rotated to introduce variation in the messaging (Laughery, Young, Vaubel, \& Brelsford, 1993; Strahan et al., 2002). No studies with pregnant women have addressed differing sizes and coloring of labels, and graphic representations of harm remain controversial as an approach for reaching and supporting pregnant women (Best Start, 2003; Poole \& Nathoo, October 2012).

Are alcohol warning labels easy to read and comprehend? It is important to make a distinction between health warning labels, which often use negative messaging to convey information about risks, and consumer information labels, which provide neutral information to consumers to help them make better choices. Debate exists about the relative effectiveness of the two approaches. Some public health experts express strong reservations about the effectiveness of consumer information labels for changing behavior, because they do not convey clear warnings about the risks, and therefore are not capable of evoking a visceral avoidance response (i.e., fear) (Agostinelli \& Grube, 2002). However, psychological research has shown that fear arousal can prompt denial, which may undermine motivation for change (Cismaru, Deshpande, Thurmeier, Lavack, \& Agrey, 2010). Such defensive responses may lead consumers to ignore precautionary instructions, or to systematically reject arguments designed to prompt precautions. While this debate continues, the most likely conclusion is that the effectiveness of different types of labels will vary across the population, and a combination of AWLs and consumer information labels has the greatest potential to encourage the safe use of alcohol.
Irrespective of the debates, studies investigating comprehension of AWL messaging suggest that understanding is enhanced when the label is prominently displayed and when it contains simple, clear and direct messages. Ambiguous or indistinct messages (e.g., "drink responsibly") do not convey meaningful information about alcohol-related risks and how to avoid them, and are therefore less likely to contribute to changes in consumer awareness (Carr-Gregg \& Lennox, 1994; Thomas, 2012; Wogalter, Conzola, \& Smith-Jackson, 2002).

Do consumers accurately recall messages on alcohol health warning labels? Argo and Main (2004) concluded that messages on health warning labels are correctly recalled by only a minority of consumers. This result was verified for pregnant women, in the case of the U.S. AWL, by Barrett, Wong and McKay (1993), who found that in a representative sample of women from Illinois, only about one-fourth of respondents were able to recall specific information about pregnancy-related risks from the warning label and from signs placed in establishments where liquor was sold.

In another study about the U.S. warning message regarding drinking in pregnancy, Hankin et al. (1993) reported significant rates of recall of warnings about birth defects among women attending an antenatal clinic. Further, Kaskutas and Graves (1994) found that women of childbearing age were especially likely to recall seeing the message about birth defects. Together, these findings indicate that message recall relates directly to the experiences and perspective of the observer; there is greater recall of warnings that have more personal relevance.

In a study of 1,100 Detroit-area women in 1995 (six years after introduction of the American AWL), Hankin, Sloan, and Sokol (1998) found that a majority (59\%) reported having seen the label in the past year, with recall being higher for older women and for women who drank more. Among women who reported seeing the AWL, a minority (25\%) correctly identified all three messages on the label. Women were less likely to correctly remember the wording on the label if they were older, drank infrequently, or did not binge drink. The authors concluded that awareness of the warning label appeared to vary across subgroups of women, and that additional prevention efforts were needed to warn women of the risks of alcohol use, including the risk associated with drinking in pregnancy.

Greenfield, Graves, and Kastutas (1999) report that for the $43 \%$ of adults in their survey who claimed to have seen the U.S. government-mandated AWLs, the message that most recalled seeing was the one that warned of "birth defects" from drinking during pregnancy. Recall of the drunkdriving message was somewhat lower and recall of the message regarding operating machinery was the lowest. This finding reflects the ordering of the messages on the U.S. label (birth defects first, drinking and driving second, and operating machinery third), suggesting that earlier messages are more memorable than later ones, and that consumers may have limited ability to remember multiple messages. 
A study of the impact of U.S. AWLs on adolescents found significant increases in recall of the messages on the labels during the period of the study, suggesting that underage drinkers saw and were able to recall messages from AWLs. However, this knowledge was not found to affect consumption (MacKinnon, Nohre, Cheong, Stacy, \& Pentz, 2001).

Do alcohol health warning labels lead to changes in judgments and values? Argo and Main (2004) concluded that health warning labels are only minimally effective in influencing consumers' perceptions of personal hazards and risk. For example, Mazis, Morris, and Swasy (1991), in two national surveys implemented six months before and six months after the introduction of the U.S. AWL in November 1989, documented only minimal changes in the public's perception of alcohol-related risk. It is possible, however, that the short follow-up of this study could have affected the results.

In another study about perceptions of risk and the U.S. AWLs, MacKinnon et al. (2001) failed to find an association between increasing awareness of the warnings and changes in beliefs about the effects of alcohol in a large sample of school-aged children. Some have suggested that the messages on the American AWL do not resonate with youth or youth culture and that this may explain their inability to change perceptions of risk among youth (Jones \& Gregory, 2009).

Positive effects on awareness of alcohol-related risk were, however, documented in one of the few evaluations of AWLs to occur outside the United States. Researchers from France (Guillemont \& Léon, 2008) surveyed representative samples of the population before (2004) and after (2007) the implementation of a mandatory AWL designed to increase awareness about the risks of drinking in pregnancy. This project documented changes in awareness of the general public on several concepts related to the recommendation of no alcohol use during pregnancy. This included increases in (1) the proportion of the respondents who believed that the risk to the fetus started with the first drink (30\% in 2007 vs. $25 \%$ in 2004), and (2) the proportion of the respondents who believed that the risk to the child from drinking is the same throughout the pregnancy (27\% in 2007 vs. $22 \%$ in 2004). These results suggest that beliefs about the risks associated with drinking alcohol during pregnancy can be affected modestly across the population by an AWL.

One significant change in attitudes that occurred with the introduction of U.S. AWLs was the increasing support for AWLs themselves (Room, Giesbrecht, Graves, \& Greenfield, 1995). For example, between 1989 and 1990, support for alcohol warning labels increased from $75 \%$ to 86\% in Canada and, in the U.S., was up to $91 \%$ by 1991 . During this period, public support for 10 other alcohol policy measures (e.g., reducing alcohol availability, restricting advertising, increasing prices for alcohol) was substantially lower and remained static or declined over time. Indeed, warning labels enjoyed the most public support of any alcohol policy measure included in the cross-national study of American and Canadian public opinion. Finally, a more recent Canadian survey verifies that a large majority of the general population continues to support AWLs, at least in concept (Giesbrecht, Ialomiteanu, \& Anglin, 2005).

Do alcohol health warning labels lead to changes in behavior? Argo and Main's (2004) meta-analysis indicated that health warning labels did, at times, influence consumer behavior; the effect was stronger when it was easier for consumers to comply with the warnings, and when consumers were more familiar with the product and its uses.

Several studies suggest that awareness of the U.S. AWLs is associated with a number of positive behavior changes, although not necessarily with decreases in alcohol consumption. For example, in repeated large-scale crosssectional national surveys, Greenfield et al. (1999) failed to find associations between increased awareness of warning labels and changes in drinking behavior. Further, MacKinnon, Pentz, and Stacy (1993) found no significant change in drinking behavior associated with an increase in awareness of AWLs among high school students. In another related study, a longitudinal analysis of students found associations between early drinking of alcohol and greater likelihood of awareness of the AWLs in later years, but there was no effect of early awareness of AWLs being a predictor of reduced drinking in later years (MacKinnon et al., 2001).

In terms of changes in other alcohol-related behaviors, Kaskutas and Graves (1994) found a significant increase, over successive U.S. population surveys, in respondents reporting that they had engaged in discussions about health consequences of alcohol consumption. Throughout the evaluation of the U.S. AWLs, this was more pronounced among those who recalled seeing only warning labels regarding birth defects, but not other health messages. Similarly, Kaskutas, Greenfield, Lee, and Cote (1998) found a direct relationship between exposure of pregnant women to warning labels regarding birth defects and the women's likelihood of discussing the topic with someone else. Greenfield et al. (1999) report that there was a decrease over time in the likelihood of respondents reporting that they drove after drinking when they "probably should not have," and that the effect was significantly greater among persons who had seen the AWLs.

More recently, it has been reported that increased awareness of the U.S. AWL regarding drinking and driving was associated with an increased probability of deterring others from drunken driving (Tam \& Greenfield, 2010). These findings are consistent with the view that the American AWLs facilitate social interventions to prevent others from driving while intoxicated.

In one of the only studies documenting positive effects of the American AWLs on drinking behaviors, Hankin, Sloan, Firestone, and Ager (1993) reported that pregnant women attending an antenatal clinic who were already light 
drinkers were significantly more likely to abstain when exposed to the warning message about birth defects. There was no significant effect for the women who were heavier drinkers. This last finding suggests that, although regular heavy drinkers are more likely to be aware of AWLs, they appear to be less likely to alter their drinking behavior, a finding replicated in other studies (Andrews, 1995; Hankin et al., 1993). This supports the hypothesis that compliance with health warning labels depends in part on the difficulty of the behavior change (Argo \& Main, 2004).

Lastly, in a large study of over 21,000 pregnant AfricanAmerican women who sought prenatal care at a university clinic over a nine-year period, Hankin et al. (1998) found a significant but modest impact of the U.S. AWL on drinking overall, with a lagged effect appearing eight months after the introduction of the warning label. This study controlled for both patient characteristics and unemployment rate, and also found that the women may have become habituated to the warning label after about six years of exposure (i.e., by 1995). According to the authors, these results provide further validation of the notion that public health messages lose their impact over time, and that more intensive interventions are needed to substantially reduce inpregnancy drinking among women over the longer term.

Another important consideration in evaluating the use of AWLs for behavior change is their potential to cause harm to some women (Caprara, Soldin, \& Koren, 2004). In particular, the language of these messages must be chosen carefully, so as not to cause unintended stress in women who consume low levels of alcohol in the time between conception and becoming aware that they are pregnant. If warnings about drinking in pregnancy are worded to imply that any alcohol use can cause serious harm to the fetus, there is some fear that women who drink lightly during the first few weeks of their pregnancy may choose to abort, even though the chances of serious birth defects are very small. For these reasons, warnings related to drinking alcohol during pregnancy should be very cautiously worded, and supplemental information should be conveyed in conjunction with such warnings, to minimize potentially harmful unintended consequences.

Other factors that impact the effectiveness of alcohol warning labels for prevention of FASD. It has not been shown that, on their own, universal interventions such as public service messages and alcohol warning labels lead pregnant women to abstain from alcohol or reduce risky consumption. However, research does suggest that AWLs can help shift social norms over the long term when they are combined and integrated with other educational, policy and programmatic initiatives (Babor et al., 2010). For example, they can help establish a general social understanding that alcohol is a hazardous commodity (Anderson, Chisholm, \& Fuhr, 2009) and therefore help promote a culture of moderation.

Universal prevention efforts, including AWLs, may lead to increased public knowledge about the risks of alcohol consumption during pregnancy, but additional strategies are required to achieve goals for prevention of FASD (Poole,
2008). For example, selective prevention reaches women of reproductive age who drink alcohol. It may involve health professionals talking to pregnant women about alcohol use, and providing women who drink with assistance in reducing or quitting alcohol and in making related improvements in their health. In many cases, selective prevention uses evidence-based brief interventions (Poole, Parkes, Urquhart, Greaves, \& Salmon, 2008). Indicated prevention reaches women with alcohol problems, and those who have a child with a FASD, through provision of long-term support and advocacy. Selective and indicated prevention initiatives support reduction in maternal alcohol use and thereby improve health outcomes for both mothers and children. Multiple measures across all three types of prevention (universal, selective and indicated) are required to shift cultural norms, understandings and behaviors. An approach to FASD prevention that integrates these mutually reinforcing levels of prevention will support cessation or reduction of alcohol use during pregnancy, improvements in the health status of girls and women, and reductions in the number of children born affected by FASD.

\section{Conclusions}

This review of the literature clearly suggests that AWLs have limited impact with respect to prevention of risky drinking during pregnancy and the occurrence of FASD. There is little or no evidence that AWLs alone are able to significantly change consumer judgments about the risks of alcohol use during pregnancy and influence drinking behavior to a degree that would make them an effective approach to prevention of FASD. That said, there is some evidence that warning labels can influence behavior when behavior change is easier, and when consumers are more familiar with products. As well, while there is no evidence that AWLs by themselves are effective for changing risky drinking, there is some evidence that they can influence several behaviors related to drinking. For example, they have been shown to stimulate conversations between pregnant women who are drinking and their health care providers, and they can encourage women who drink lightly to abstain from alcohol while pregnant. However, research does not show that AWLs are effective for changing judgments and beliefs about alcohol, or reducing risky consumption among maternal drinkers who consume heavily and frequently.

Public messaging campaigns that incorporate advances in prevention-messaging science and practice, coupled with better label design, would likely improve the ability of warning labels to help change cultural norms and behavior around alcohol. Selective and indicative prevention initiatives, serving the needs of women of prime childbearing ages who drink and higher-risk women who may already be engaging in maternal drinking, should be pursued simultaneously and integrated with universal prevention programs such as AWLs to maximize effectiveness.

The role that AWLs can play in shifting the general drinking culture and, more specifically, in reducing the prevalence of heavy drinking among women of 
childbearing age, is worth considering in future studies. Universal prevention interventions, such as warning labels and public messaging campaigns, when carefully designed, can play a positive role in multifaceted FASD prevention strategies.

\section{Limitations}

This is a small scoping study, intended to provide evidence and recommendations to policy makers considering action on the labeling of alcohol products as a strategy in the prevention of FASD. Limited research has been done specifically on the role of AWLs in influencing the behavior of women who drink alcohol in pregnancy; as such, this research is considered in light of what is known about the effectiveness of alcohol labeling in general.

\section{References}

Agostinelli, G., \& Grube, J. (2002). Alcohol counteradvertising and the media: A review of recent research. Alcohol Research \& Health, 26, 15-21.

Anderson, P., Chisholm, D., \& Fuhr, D. (2009). Effectiveness and cost-effectiveness of policies and programmes to reduce the harm caused by alcohol. Lancet, 372, 2234-2246.

Andrews, J. (1995). The effectiveness of alcohol warning labels: A review and extension. American Behavioral Scientist, 38, 622-632. doi:10.1177/000276429503 8004011

Argo, J., \& Main, K. (2004). Meta-analyses of the effectiveness of warning labels. Journal of Public Policy \& Marketing, 23, 193-208.

Babor, T., Caetano, R., Casswell, S., Edwards, G., Giesbrecht, N., \& Graham, K. (2010). Alcohol: No ordinary commodity. 2nd edition. New York, NY, United States: Oxford University Press.

Barrett, M. E., Wong, F. Y., \& McKay, D. R. (1993). Selfreported alcohol use among women of childbearing age and their knowledge of alcohol warning labels and signs. Archives of Family Medicine, 2, 1260-1264.

Best Start. (2003). Keys to successful alcohol and pregnancy communication campaigns. Toronto, ON: Best Start: Ontario's Maternal, Newborn and Early Child Development Resource Centre.

Caprara, D., Soldin, O., \& Koren, G. (2004). To label or not to label: The pros and cons of alcohol warning labels in pregnancy. Journal of FAS International, e:9, $1-3$.

Carr-Gregg, M., \& Lennox, N. (1994). “According to the Surgeon General ...” Is there a case for warnings on alcohol advertisements in Australia? Health Promotion Journal of Australia, 4, 22-25.

Cismaru, M., Deshpande, S., Thurmeier, R., Lavack, A. M., \& Agrey, N. (2010). Preventing fetal alcohol spectrum disorders: The role of protection motivation theory. Health Marketing Quarterly, 27, 66-85.

Eurocare. (2011). What's not on the bottle? Brief overview of the state of play in alcohol labeling, November 2, 2012. Retrieved from http://www.eurocare.org/ resources/policy_issues/alcohol_and_pregnancy/euroc are_papers/what_s_not_on the bottle_brief_overview _of_state_of_play_in_alcohol_labelling_december_20 11

Giesbrecht, N., Ialomiteanu, A., \& Anglin, L. (2005). Drinking patterns and perspectives on alcohol policy: Results from two Ontario surveys. Alcohol \& Alcoholism, 40, 132-139. doi:10.1093/alcalc/agh120

Greenfield, T. (1997). Warning labels: Evidence on harm reduction from long-term American surveys. In $\mathrm{M}$. Plant, Single, E., \& Stockwell, T. (Eds.), Alcohol: Minimizing the harm. London, United Kingdom: Free Association Books.

Greenfield, T. K., Graves, K. L., \& Kaskutas, L. A. (1999). Long-term effects of alcohol warning labels: Findings from a comparison of the United States and Ontario, Canada. Psychology \& Marketing, 16, 261-261.

Guillemont, J., \& Léon, C. (2008). Alcool et grossesse: connaissances du grand public en 2007 et évolutions en trois ans [Alcohol and pregnancy: Public knowledge in 2007 and its changes over three years]. Évolutions, 15.

Hankin, J. R., Firestone, I. J., Sloan, J. J., Ager, J. W., Sokol, R. J., \& Martier, S. S. (1996). Heeding the alcoholic beverage warning label during pregnancy: Multiparae versus nulliparae. Journal of Studies on Alcohol, 57, 171-177.

Hankin, J. R., Firestone, I. J., Sloan, J. J., Ager, J. W., Goodman, A. C., Sokol, R. J., \& Martier, S. S. (1993). The impact of the alcohol warning label on drinking during pregnancy. Journal of Public Policy \& Marketing, 12, 10-18.

Hankin, J. R., Sloan, J. J., Firestone, I. J., \& Ager, J. W. (1993). A time series analysis of the impact of the alcohol warning label on antenatal drinking. Alcoholism: Clinical and Experimental Research, 17, 284-289.

Hankin, J. R., Sloan, J. J., \& Sokol, R. J. (1998). The modest impact of the alcohol beverage warning label on drinking during pregnancy among a sample of African-American women. Journal of Public Policy \& Marketing, 17, 61-69.

Jones, S. C., \& Gregory, P. (2009). The impact of more visible standard drink labelling on youth alcohol consumption: Helping young people drink (ir)responsibly? Drug and Alcohol Review, 28, 230234. doi:10.1111/j.1465-3362.2008.00020.x

Kaskutas, L. A., \& Graves, K. (1994). Relationship between cumulative exposure to health messages and awareness and behavior-related drinking during pregnancy. American Journal of Health Promotion, 9, 115-124.

Kaskutas, L., \& Greenfield, T. K. (1992). First effects of warning labels on alcoholic beverage containers. Drug and Alcohol Dependence, 31, 1-14.

Kaskutas, L., \& Greenfield, T. (1997). Behaviour change: The role of health consciousness in predicting attention to health warning messages. American Journal of Health Promotion, 11, 183-193.

Kaskutas, L. A., Greenfield, T., Lee, M. E., \& Cote, J. (1998). Reach and effects of health messages on drinking during pregnancy. Journal of Health Education, 29, 11-20. 
Laughery, K., Young, S., Vaubel, K., \& Brelsford, J. (1993). The noticeability of warnings on alcoholic beverage containers. Journal of Public Policy \& Marketing, 12, 38-56.

MacKinnon, D. P., Nohre, L., Cheong, J., Stacy, A. W., \& Pentz, M. A. (2001). Longitudinal relationship between the alcohol warning label and alcohol consumption. Journal of Studies on Alcohol, 62, 221227.

MacKinnon, D. P., Pentz, M. A., \& Stacy, A. W. (1993). The alcohol warning label and adolescents: The first year. American Journal of Public Health, 83, 585587.

Mazis, M. B., Morris, L. A., \& Swasy, J. L. (1991). An evaluation of the alcohol warning label: initial survey results. Journal of Public Policy \& Marketing, 10, 229-241.

Poole, N. (2008). Fetal Alcohol Spectrum Disorder (FASD) prevention: Canadian perspectives. Ottawa, Ontario: Public Health Agency of Canada.

Poole, N., \& Nathoo, T. (2012, October). The politics of alcohol and pregnancy awareness campaigns. Paper presented at the 2nd European Conference on FASD: Fetal Alcohol Spectrum Disorders: Clinical and biochemical diagnosis, screening and follow-up, Barcelona, Spain.

Poole, N., Parkes, T., Urquhart, C., Greaves, L., \& Salmon, A. (2008, September). Double exposure: A better practices review on alcohol interventions during pregnancy. Paper presented at the 9th Annual Fetal Alcohol Canadian Expertise (FACE) Research Roundtable, Montreal, QC.

Room, R., Giesbrecht, N., Graves, K., \& Greenfield, T. (1995). Trends in public opinion about alcohol policy initiatives in Ontario and the U.S. 1989-91. Drug and Alcohol Review, 14, 35-47.

Strahan, E. J., White, K., Fong, G. T., Fabrigar, L. R., Zanna, M. P., \& Cameron, R. (2002). Enhancing the effectiveness of tobacco package warning labels: a social psychological perspective. Tobacco Control, 11, 183-190. doi:10.1136/tc.11.3.183

Tam, T. W., \& Greenfield, T. K. (2010). Do alcohol warning labels influence men's and women's attempts to deter others from driving when intoxicated? Human factors and ergonomics in manufacturing \& service industries, 20, 538546.

Thomas, M. (2012). Alcohol warning labels: Do they work? Australian Parliamentary Library Background Note. Retrieved from http://observgo.uquebec.ca/ observgo/fichiers/74317_1622273.pdf

Wilkinson, C., \& Room, R. (2009). Warnings on alcohol containers and advertisements: international experience and evidence on effects. Drug and Alcohol Review, 28, 426-435.

Wogalter, M. S., Conzola, V. C., \& Smith-Jackson, T. L. (2002). Research-based guidelines for warning design and evaluation. Applied Ergonomics, 33, 219-230. 